\title{
磁気ディスクとダイヤモンド触針との間に形成される 分子液架橋のばね定数と減衰係数の測定*
}

\author{
三矢 保 永 $^{* 1}$, 大島 康 司 ${ }^{* 2}$, 張 賀 東*3 \\ 青山 慶*4, 河 合敏 行*5, 福澤健 二*3
}

Stiffness and Damping of Molecularly Thin PFPE Lubricant Bridging between Magnetic Disk and Diamond Probe Tip

Yasunaga MITSUYA*6, Yasuji OHSHIMA, Hedong ZHANG,

Kei AOYAMA, Toshiyuki KAWAI and Kenji FUKUZAWA

${ }^{* 6}$ Department of Micro-Nano Systems Engineering, Graduate School of Engineering, Nagoya University, Furo-cho, Chikusa-ku, Nagoya-shi, Aichi, 464-8603 Japan

The spring constants and damping coefficients of molecularly thin liquid bridges of PFPE lubricant forming between a diamond tip and DLC surface of a magnetic disk are estimated by means of regression analysis of tip damping vibration. Two PFPE lubricants having functional end groups (Zdol 2000 and Zdol 4000) with respective thicknesses of roughly $20 \mathrm{~nm}$ and $40 \mathrm{~nm}$, were coated on a DLC disk surface in order to form a liquid bridge between the disk and the probe tip. This tip, with an exceptionally small curvature radius of $0.1 \mathrm{~mm}$, was in separate experiments both retracted from and extended toward the disk surface in a stepwise motion, and the liquid bridge was made to vibrate at each step. By applying regression analysis to observed waveforms, the spring constant and the damping coefficient of the liquid bridge were estimated within an elongation range from 50 to $800 \mathrm{~nm}$. The spring constant, $k_{m}$, of the liquid bridge had negative values varying from -0.15 to $-0.1 \mathrm{~N} / \mathrm{m}$. Damping values expressed in the form of frequency-multiplied damping coefficients, $c_{m} \times \omega$, ranged from 0.02 to $0.06 \mathrm{~N} / \mathrm{m}$. It is interesting to note that both $\left|k_{m}\right|$ and $c_{m} \times \omega$ decreased with bridge elongation, and after reaching the minimum, those values began to increase.

Key Words : Meniscus, Liquid Bridge, Thin Lubricant, PFPE, Adhesion Force, Lubricant Elongation, Magnetic Disk, Probe Tip

\section{1. まえがき}

マイクロ・ナノテクノロジーの分野では, 単分子レ ベルの高分子の変形量や作用力を定量化するという技 術課題がある. 例えば, 磁気ディスク装置においては, ディスク表面に塗布されている単分子膜厚さ $(1.5 \sim 2$ $\mathrm{nm}$ )の潤滑剤(ナノ潤滑剂)が，ヘッドと接触した場合 の挙動を評価する手段として，その動的特性を解明す ることが課題となっている。 また,ナノバイオテクノ ロジーの分野では，単一の夕ンパク質の力変位特性が, タンパク質の構造解析の一手法として採用されてい る.

分子層レベルの液体薄膜の動的特性については, 一 方の面を往復加振して, 他方の面の応答特性を測定し, 伝達関数として粘弾性特性を求める方法が採用されて きた. 研究の流れとしては, せん断方向の特性と法線

\footnotetext{
* 原稿受付 2004 年 7 月 26 日

*1 正員, フェロー, 名古屋大学大学院工学研究科( $\boldsymbol{M} 464-8603$ 名古屋市千種区不老町)

*2 正員, 愛知江南短期大学現代幼児学料( - 483-8086 江南市 高屋町大松原 172)

*3 正員, 名古屋大学大学院工学研究科.

*4 宇宙通信 (株) ( 140-0002 東京都品川区東品川 2-2-8)

*5 名古屋大学大学院工学研究科.

E-mail : mitsuya@nuem.nagoya-u.ac.jp
}

方向の特性の測定がある。これまで, せん断方向につ いては, 主として表面力解析装置(Surface Force Apparatus) が使用され，二つの透明な半円筒(曲率半 径 $10 \mathrm{~mm}$ ）を十字形に交差させ, 高荷重を与えてすき まがほほ平行になるように変形させて, ナノ閉じこめ 状態における粘弾性特性が測定された(1).また，微小 な二つの球 (曲率半径が $90 \mu \mathrm{m}$ と $20 \mu \mathrm{m}$ )を対向させ て, 数十〜数百 $\mathrm{nm}$ のすきまにおけるせん断時の粘弾 性特性が測定された(2).一方, 著者らは摺動子として 先端を球状 (曲率半径 $200 \mu \mathrm{m}$ ) に形成した光ファイバ を用いて，ナノメートルのすきまを介した相対運動に おける粘弾性特性を測定した ${ }^{(3)}$. 法線方向の特性につ いては, 平面と球面(曲率半径 $10 \mathrm{~mm}$ )の間に, メ二ス カスを形成して, 数十〜数百 $\mu \mathrm{m}$ のすきまにおけるメ ニスカスのばね定数と減衰係数が測定された(4). 最近 では, 微小な二つの球(曲率半径がともに $20 \mu \mathrm{m}$ )を対 向させて, 数十〜数百 $\mathrm{nm}$ のすきまにおける粘弾性特 性が測定された(5).

磁気ディスクにおいては，浮上すきまが $10 \mathrm{~nm}$ まで 微小化されるに及んで, ヘッドとディスクとの接触の 機会 (間欠的な接触)が増大しており，信頼性・耐久性 を支配する要因として，ナノ潤滑膜の動的特性を定量 化する必要性が高まっている，特に，間欠的な接触が 
致命的な破壤に至らない場合と，致命的な破壊に至る 場合の境界条件を明確にすることが，さらにすきまを 微小化するための重要な課題になっている．法線方向 の粘弾性特性を測定する従来の方法 ${ }^{(5)}$ は，摺動子の曲 率半径が $20 \mu \mathrm{m}$ であり，膜厚さに比較すると桁違いに 大きいために、ヘッドとディスクの接触・非接触の境 界近傍に扔いて形成される微細な液架橋の動的特性を 適確に表していることにはならない.

著者らはこれまでにダイヤモンド触針(先端の曲 率半径 $0.1 \mu \mathrm{m}$ ) 付きのプローブを用いて, PFPE系の 潤滑膜の塗布された磁気ディスクに触針を接触させ て，プローブを引上げたときに生起されるプローブの 過渡振動により，潤滑剤の液架橋に作用する力と伸び 量を測定する方法を開発した ${ }^{(6)(7)}$. 本報では，この力 法を拡張して, プローブを引上げて, 液架橋を伸ばし た状態に維持したままで，プローブに過渡振動を発生 させて，この減衰振動波形を回帰分析することにより， 粘弾性特性を測定寸る方法を導入した。また，本方法 を用いて，磁気ディスクで使用されている PFPE系潤 滑剤(Zdol 2000, Zdol 4000)について, 液架橋が切断 される直前の極めて微細な液架橋のば权定数・減衰係 数を測定することに初めて成功した。ば权定数(絶対 値)，減衰係数とも，架橋の伸びとともに減少し，最小 值をとったのちに増加に転じるという興味ある特性が あることを見出した。

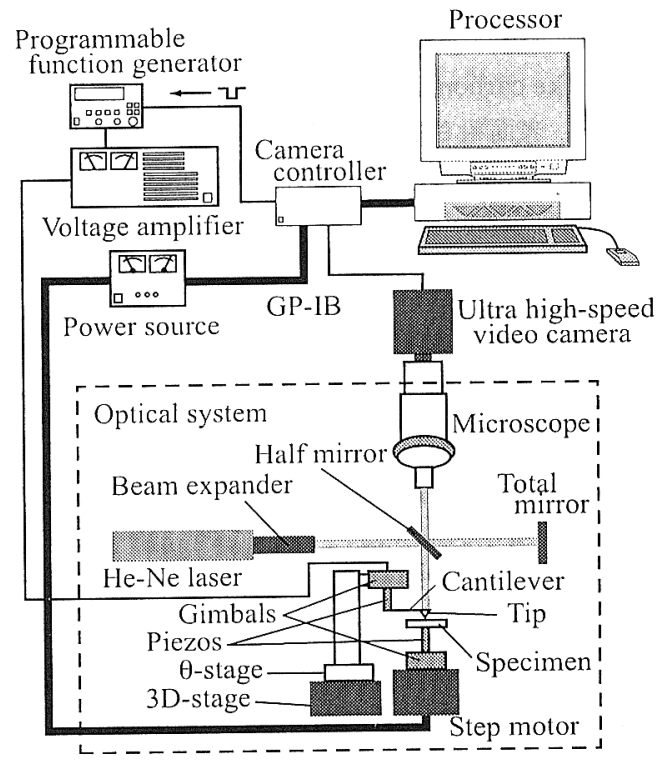

Fig. 1 Schematic diagram of experimental apparatus

\section{2. 実験装置と実験手順}

$2 \cdot 1$ 実験装置＼cjkstart実験装置の概略を図 1 に示す。 基本的には前報(7) の構成と同じであり，概要のみを説 明する。

He-Ne レーザからの光ビームは, ビームエキスパ ンダを通して 10 倍に拡大され，ハーフミラーにより 2 本のビームに分割されて, 物体面(カンチレバー)と参 照面(全反射ミラ一)に入射する．物体面と参照面加ら の反射光は，ハーフミラーで合成され，顕微鏡を通し て拡大されて，撮像素子面に干涉縞を形成する。撮像 素子としては超高速力メラ(最高40500コマ/秒)を用 い,カンチレバーの動的な変動に伴う干渉縞画像の変 化を連続的に撮影する。触針を上下駆動するために， カンチレバーはピエゾアクチュエータ (PZT)に固定 され、このPZT を搭載しているジンバルによりピッ チング角とローリング角が微調整される。一方, 試料 台もジンバルに搭載され，微動用の PZTと粗動用の z軸マイクロステージにより垂直方向に位置決めす る。

$2 \cdot 2$ 触針の仕様触針としては，先端を三角錐 に形成したダイヤモンドを使用した。電子顕微鏡写真 を図 2 に示す。先端の曲率半径は $100 \mathrm{~nm}$ である.力 ンチレバーはステンレス製で, 厚さ $20 \mu \mathrm{m}$, 幅 0.2 $\mathrm{mm}$, 全長 $8.1 \mathrm{~mm}$ で, PZT に接着した後のたわみ部 の長さ(有効長さ)は $4.47 \mathrm{~mm}$ である. カンチレバー の触針の背面にはシリコン板を接着固定して，この表 面上にマイケルソン干渉縞を形成した。ダイヤモンド 触針，シリコン板，カンチレバーたわみ部の質量の計 算值は，それぞれ $31.6 \mu \mathrm{g}, 9.3 \mu \mathrm{g}, 141.4 \mu \mathrm{g}$ である。

カンチレバーのばね定数は, カンチレバーの幾何学 的形状から計算した。計算に必要な有効長さを精度良

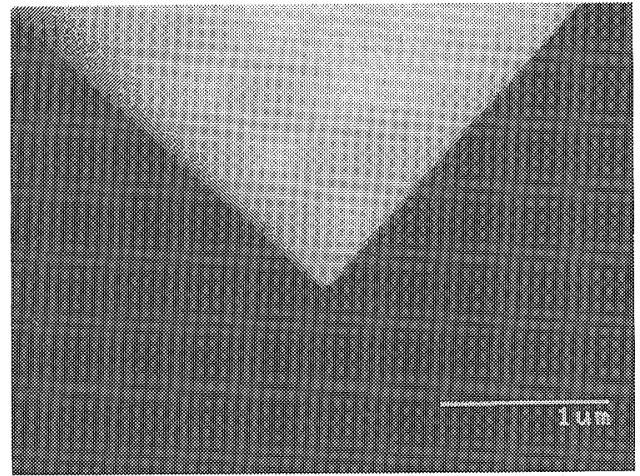

Fig. 2 Image of probe tip taken with by scanning electron microscope 
く測定することは困難であるので, 先端の集中質量 (触針とシリコン板) とカンチレバーに沿う分布質量を 持つ振動系として振動解析を行い, 計算で得られた固 有振動数と実測值の固有振動数を比較して, 両者が一 致するように計算で使用するたわみ部長さを補正し て, 一致した值を有効長さとした. 今回の実験系では, たわみ部の長さの測定値 $4.5 \mathrm{~mm}$ に対し, 測定した固 有振動数に基づいて補正した有効長さは $4.47 \mathrm{~mm}$ で, その差はわずか $0.7 \%$ 崖り,よい精度で振動系が同 定されたとえいる．有効長さを用いて計算される第一 次モードの振動としてのばね定数と等価質量を, 以下 の振動解析に使用した。それぞれ，0.856 N/m, 65.0 $\mu \mathrm{g}$ である.

$2 \cdot 3$ 実験手順 実験手順は以下のとおりである. (1) カンチレバー表面と試料表面上の両方に干涉縞を 形成し，(2)カンチレバー側の PZTを最大に伸ばし た状態において, 試料側の $z$ 軸マイクロステージと $\mathrm{PZT}$ を用いて試料を触針に接触させ, (3) 超高速力 メラの撮影関始と同期した信号により, カンチレバー 側の PZT を縮めて, カンチレバーを上昇させ, 触針 を試料表面から引き離す。（4)撮影開始からの干涉縞 の変化を連続画像として処理し，カンチレバーの変位 を求める。撮影した縞画像から，カンチレバーの変位 を求める画像処理手順については, 前報と同じである ので,ここでは説明を省略する.なお，後述の実験に おいては, 2.02 秒間において, 縞画像を合計 81810 枚 採取し, 画像解析により, 触針の変位を求めた。

架橋が形成された状態の振動系は, 剛性が極めて小 さい微妙な系であり, わずかの外乱によっても, 振動

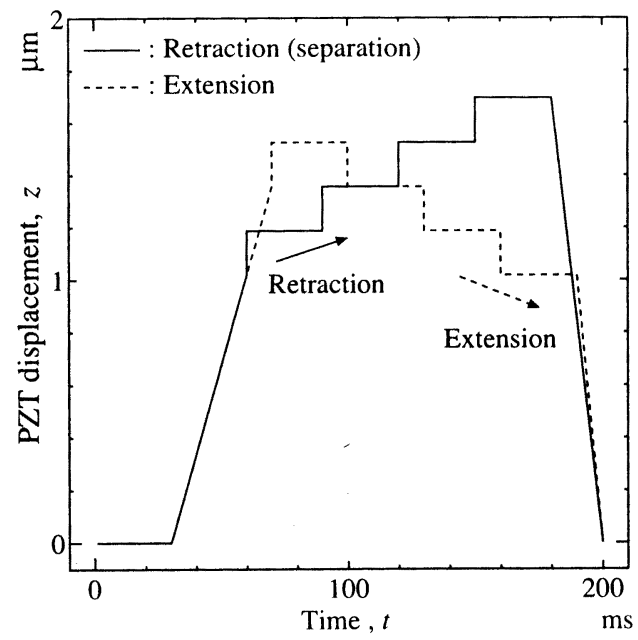

Fig. 3 Stepwise movement of cantilever
が誘起される.この影響を抑制するために，装置を空 気ばね式の除振台に搭載し，かつ実験は外乱が最小と なる深夜に実行した。

2・4 カンチレバーの多段階駆動の蓄入 本報に おいて, 新しく導入した点は, カンチレバー側の PZT を駆動する電圧波形を発生させるために, 関数発生器 を用いたことである。これによって，カンチレバーを 任意の時間軌跡で引上げられるようになり, 液架橋が 伸びた状態において, 過渡振動を発生させ, その減衰 振動波形を観測することにより，伸び量に対応した動 特性を測定できるようになった。さらに, 液架橋が切 断される直前の状態に維持しておけば, 極微細な液架 橋の動特性の測定が可能である。

本報では，プローブの上昇過程における四段階の引 上げと, 下降過程における四段階の引下げを行うこと とした。それぞれにおける PZT 駆動電圧の時間軌跡 を図 3 に示す，上昇過程においては，最初の引上げ区 間では傾斜を設けて (速度を落として引上げる), この 区間で過渡振動が発生しないようにした。傾斜区間の 終了後に, ステップ状に電压を上昇させて, 過渡振動 を発生させた。下降過程においては,いったん最大電 圧を与えてから，階段状に電圧を下降させた．上昇過 程と下降過程の二つの条件を設けた理由は, 液架橋内 部において，分子の流動に起因するクリープ現象の発 生の有無を確認するためである.

2.5 供試ディスクと潤滑剤の仕様供試ディス クとしては, ガラス基板を用いた 2.5 インチサイズの 実用品を使用した。表面にはイオンビーム法により， 水素添加のダイヤモンドライクカーボン (DLC : diamond like carbon) が形成されている. DLC 膜の厚さ は $3 \mathrm{~nm}$, 表面粗さは $R_{a}=0.6 \mathrm{~nm}, R_{\max }=5 \sim 8 \mathrm{~nm}$ で ある.潤滑剤としては, PFPE(perfluoropolyether) Zdol 2000 と Zdol 4000 を使用した。この潤滑剤は, $\mathrm{X}-\mathrm{CH}_{2}-\mathrm{CF}_{2}-\mathrm{O}-\left(\mathrm{CF}_{2}-\mathrm{CF}_{2}-\mathrm{O}\right)_{m}-\left(\mathrm{CF}_{2}-\mathrm{O}\right)_{n}-\mathrm{CF}_{2}-$ $\mathrm{CH}_{2}-\mathrm{X}\left(\mathrm{X}=\mathrm{CF}_{2} \mathrm{CH}_{2} \mathrm{OH}, m / n \approx 2 / 3\right)$ の構造を持つ 直鎖状の高分子で, Zdol 2000, Zdol 4000 の分子量は それぞれ，2000，4000である．また，それぞれの潤滑 剂の一つの分子の大きさに関して, 分子回転半径は, $1.1,1.5 \mathrm{~nm}$, 分子を直線的に伸ばしたときの長さは, $7,14 \mathrm{~nm}$, 分子の太さは, ともに $0.7 \mathrm{~nm}$ と見積もら れている。

潤滑剤は, フレオン系の溶媒(hydrofluoroether) HFE 7200 (構造式： $\mathrm{C}_{4} \mathrm{~F}_{9} \mathrm{OC}_{2} \mathrm{H}_{5}$ ) で希釈し,ディップ コーティング法により，ディスク面上に塗布した。希 釈度の範囲は, 2.5 5.5\%. 引上げ速度は, 一定の 2.5 $\mathrm{mm} / \mathrm{s}$ とした。塗布した後の潤滑膜の厚さは, 走査形 
エリプソメータ (Five Laboratory 社：MARY 102) で測定した．潤滑膜の厚さは，液架橋の形成を容易に するために，実用ディスクの場合より厚くして，薄い 場合を 22〜24 nm, 厚い場合を 44〜 49 nmとした。実 験した液架橋の伸びは，おおよそ50〜800 nm の範囲 である．実験は同一の条件に扔いて，ディスクの場所 を変えて複数回行った，触針への潤滑凨の付着効果を 除去するために，触針先端部は実験ごとに毎回洗浄し t.

\section{3. 過渡振動における}

\section{振動パラメータの同定法}

液架橋が形成された状態におけるカンチレバーの振 動系のモデルを図 4 に示す. 先端部の等価集中質量 $m$ が, カンチレバーのばねとダンパ(ばね定数 $k_{c}$, 減 衰係数 $\left.c_{c}\right)$ と液架橋のばねとダンバ(ばね定数 $k_{m}$, 減 衰係数 $c_{m}$ ) で支持されている. 触針の変位を $z$, 引上 げ用 PZT の変位を $z_{p}$ とすれば，運動方程式は以下の ように表される。

$$
m \frac{\mathrm{d}^{2} z}{\mathrm{~d} t^{2}}=-k_{c}\left(z-z_{p}\right)-c_{c}\left(\frac{\mathrm{d} z}{\mathrm{~d} t}-\frac{\mathrm{d} z_{p}}{\mathrm{~d} t}\right)-F_{m}
$$

ここで， $F_{m}$ は液架橋に作用する力で，静的な力を $F_{0}$ とすれば，以下のように表される。

$$
F_{m}=k_{m} z+c_{m} \frac{\mathrm{d} z}{\mathrm{~d} t}+F_{0}
$$

式（1）の自由振動解における対数減衰率と角固有振動 数は次式で与えられる.

$$
\begin{aligned}
& n_{b}=\frac{c_{c}+c_{m}}{2 m} \ldots \ldots \ldots \ldots . . \\
& \omega_{b}=\sqrt{\frac{k_{c}}{m}+\frac{k_{m}}{m}-n_{b}^{2}}
\end{aligned}
$$

式 $(4)$ から, 液架橋のばね定数は, 以下のように求め られる。

$$
k_{m}=\left(\omega_{b}^{2}+n_{b}^{2}-\frac{k_{c}}{m}\right) m
$$

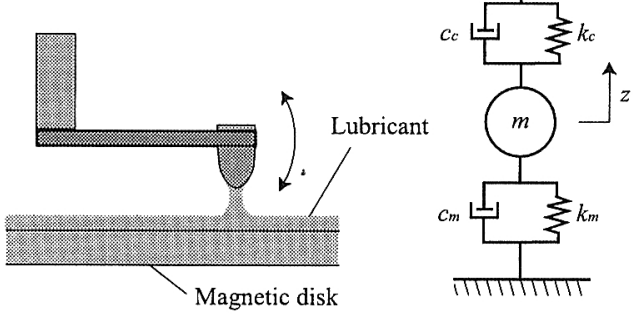

Fig. 4 Vibration system model
等価質量は，実測した量ではないために，不確かさ が大きい，そこでこれを実測できる量に変換する，液 架橋が形成されていないときの自由振動の対数減衰 率, 角固有振動数を $n_{0}, \omega_{0}$ とすると, それぞれ以下の ように与えられる。

$$
\begin{aligned}
& n_{0}=\frac{c_{c}}{2 m} \cdots \cdots \cdots \\
& \omega_{0}=\sqrt{\frac{k_{c}}{m}-n_{b}^{2}}
\end{aligned}
$$

式(6)，（7)より $m$ を求め, 式(5)，(3)に代入すれ ば，次式を得る。

$$
\begin{aligned}
& k_{m}=\left(\omega_{b}^{2}+n_{b}^{2}-\omega_{0}^{2}-n_{0}^{2}\right) \frac{k_{c}}{\omega_{0}^{2}+n_{0}^{2}} \\
& c_{m}=\frac{k_{c}}{\omega_{b}^{2}+n_{b}^{2}} n_{b}-c_{c}
\end{aligned}
$$

以下のパラメータ同定に扔いては，液架橋がある場 合と，ない場合に観測された振動波形を用いて，最小 二乗法に基づく回帰分析により，角固有振動数と対数 減衰率を同定し，それぞれ式(8)，(9)に代入して, ばね定数と減衰係数を求めた。

\section{4. パラメータ同定結果と考察}

$4 \cdot 1$ ばね定数の同定結果 触針の上昇時と下降 時の振動波形の代表例を図 5(a)，（b)に示す。回帰 分析によって同定した固有振動数も図中に合わせて示 した。引上げ時には，3段めまでお扔むね類似の波形 が観測されているが，詳細にみると，1段めのほうが 減衰が早い.4段めでは振動が急速に減衰し, 減衰後 に静的なバランス状態には維持されずに,クリープし て分離が始まり, 最終的に破断してカンチレバーの片 持支持の自由振動が始まる. 固有振動数は, 液架橋の 伸びとともに上昇して最大值をとった後に減少に転じ ることがわかる４４段めに扔いて，振動が急速に減衰 することは，切断直前に扝いて減衰係数が急上昇する ことを示している.なお，4段めの減衰振動が収歛し た後にクリープして破断する例は偶然観測されたも のである。

下降時の特性も基本的には同じであり，固有振動は， 下降に伴いいったん増加して最大值をとったのちに， 再び減少する．また，液架橋が最も伸びた状態におけ る振動は急速に減衰するが，他の段階における過渡振 動は上昇時と類似していることがわかる.なお昇時 も下降時も基本的には, 同様の特性が得られるので, 以下のパラメータ同定の結果は, 上昇時の場合のみを 示す.

Zdo1 2000 の膜厚さが $24 \mathrm{~nm}$ の場合について, 液架 橋のばね定数の同定結果を図 6 に示す。異なる測定点 
において複数回行った結果をまとめたものである。実 験ごとのばらつきがあるのは, ディスク表面の場所に よって潤滑膜の厚さやその存在形態が局所的に変動し ている影響と思われる。しかしその変動幅は小さく， よい再現性が得られているといえる.

液架橋は負のばね特性を示す(伸びるに従って作用 する力が小さくなる)ので，その大きさを絶対值 $\left|k_{m}\right|$ で評価することにする. $\left|k_{m}\right|$ は $0.1 \sim 0.15 \mathrm{~N} / \mathrm{m}$ 程度 であり，伸びるに従って小さくなり，最小値をとった 後に増加するという興味ある特性を示すことがわか る.

なお,ばね定数の変化に応じて, 振動数も変化する が，カンチレバーのばね定数に比較して，液架橋のば ね定数は小さいため, 実験条件における振動数の変動

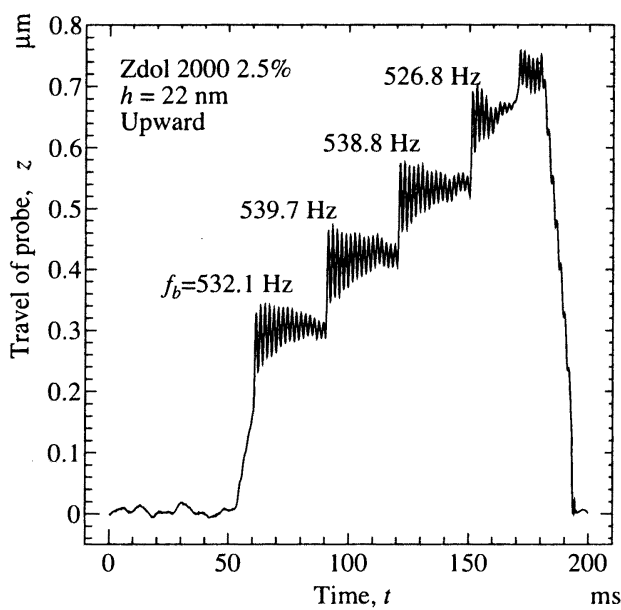

(a) While tip retracting

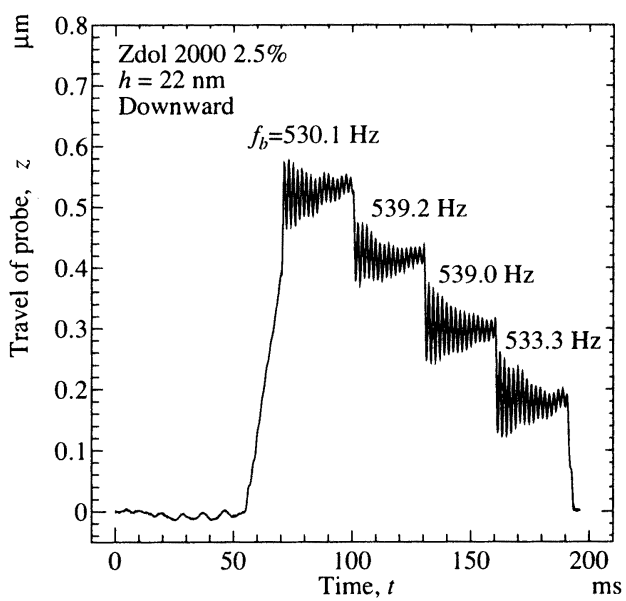

(b) While tip extending

Fig. 5 Typical waveforms for Zdol 2000 with film thickness of $22 \mathrm{~nm}$
範囲は, $520 〜 540 \mathrm{~Hz}$ と狭い. したがって,ここで得 られた結果は, 周波数がほほ一定の条件における特性 といえる。

膜を厚くした場合 $(49 \mathrm{~nm})$ の結果を図 7 に示す. 膜 が薄い図 6 に比較して, 減少の領域が広いことがわか る.これは, ばね定数の減少が飽和する特性, あるい は増加に転じる特性は, 液架橋が細く伸びたときに生 じることを示唆している.

Zdol 2000 に比較して分子量が 2 倍に大きい Zdol 4000 の場合について, 膜厚さが $24 \mathrm{~nm}$ の結果を 図 8 に示す. $\left|k_{m}\right|$ の大きさはZdol 2000 の場合とほほ 同じであるが, 伸びに対する飽和開始点が伸びの長い 側へ移動していること, 最小值をとった後に増大に転 じる特性が顕著であることに差異が認められる。この 差異は, 図 9 に示すように膜を厚くした場合 $(44 \mathrm{~nm})$ も同様であり，Zdol 2000 に比較して分子が長い特性 が反映されたものと解釈できる。印は最終段に引上 げる過程で破断した場合であり,このときには, カン チレバーのみのばね定数を求めたことになるが, 参考 値として示した。

$4 \cdot 2$ 減衰係数の同定結果振動現象における減 衰の大きさを表す方法としては, 減衰係数, 減衰係数 ×角振動数, 減衰比などがあるが, ここでは, 粘弾性 的な特性を表す場合に使用されている減衰係数×角振 動数を使用することにする。この場合には, ばね定数 と同じ単位となり, 粘性効果と弾性効果の比較が容易 である。

潤滑剂が Zdol 2000, 膜厚さが $22 \mathrm{~nm}$ の場合につい て, 液架橋の減衰係数の同定結果を図 10 に示す. 減 衰係数 $\times$ 角振動数の值はおおむね $0.02 \sim 0.06 \mathrm{~N} / \mathrm{m}$ の範囲にあり, 伸びとともに減少し, 最小値をとった 後に増加する特性は注目に値する。特に高い減衰を示 した点は, 図 5 ( a )に示した最終段の後に膜がクリー プ破断に至った場合である。印は最終段に引上げる 過程で破断した場合であり，このときには，カンチレ バーのみの減衰係数を求めたことになるが, 参考值と して示した。

図 11 に膜厚さを $49 \mathrm{~nm}$ に厚くした場合の結果を示 す. 基本的な特性は薄い場合と類似しているが, 伸び に対する飽和が膜の厚い側へ伸びており，この範囲で は減衰の急増は観測されなかった。

$Z$ dol 4000 の場合の膜厚さが $24 \mathrm{~nm}$ の結果を図 12 に示す。減衰係数 $\times$ 角振動数の大きさはZdol 2000 の 場合とほほ同じであるが，伸びに対する飽和開始点が 伸びの長い側へ移動していること, 最小值をとった後 に増大に転じる特性が顕著であることに差異が認めら 
れる.この差異は, 図 13 に示すように膜を厚くした 場合 $(46 \mathrm{~nm})$ も同様であり, Zdol 2000 に比較して分 子鎖が長い特性が反映されたものと解釈できる.

ここで，伸びに伴う減衰係数の増減が，伸びが小さ い領域と，伸びが大きい領域で逆転する特性について 考察する。直鎖状のPFPE分子は，ディスク表面で は，押しつぶされた球のような形態で存在し，引上げ 前の状態では，多数の PFPE 分子が触針との接触部の 周辺にメニスカスを形成していると考えられる。ま た，分子運動に比較して，触針の振動速度は十分遅い ため, 分子の変形は瞬時に回復されると考えられる. したがって，分子変形の影響は小さく，図 14 に示すよ うに, 分子の移動によって液架橋が伸びると考えられ

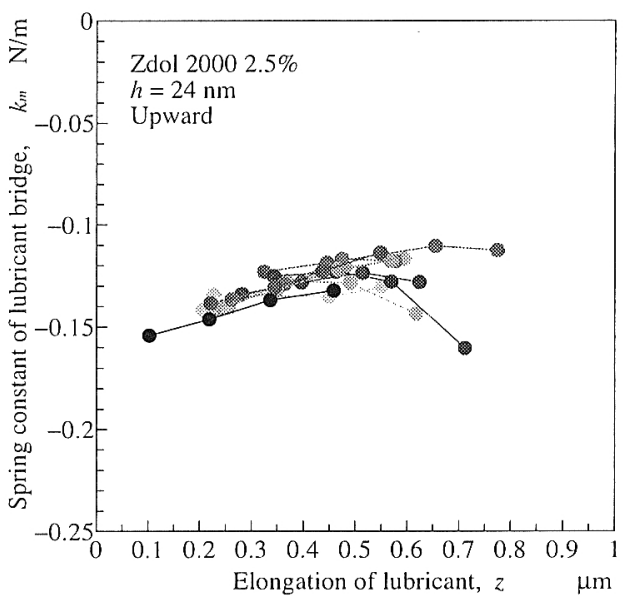

Fig.6 Identified spring constant relative to bridge elongation for Zdol 2000 with film thickness of $24 \mathrm{~nm}$

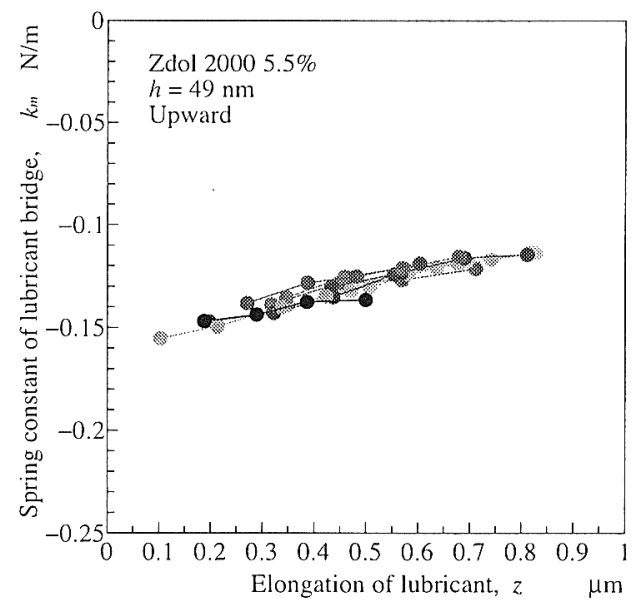

Fig. 7 Identified spring constant relative to bridge elongation for Zdol 2000 with film thickness of $49 \mathrm{~nm}$
る.このような状態において, 減衰に関連する要因と しては, 粘性流体としてのスクイーズ効果と, メニス カスの運動のヒステリシス (wetting と dewetting の 差)が考えられる.振動数が活ぼ一定であるので, ス クイーズ効果は伸びの二乗に反比例すると考えられ る、メニスカスのヒステリシスとしては, 液体と固体 の境界位置が固定され, 液表面の曲率が変化するモデ ル(接触角変動モデル) と, 液表面の曲率が固定され, 境界位置が変化するモデル(境界位置変動モデル)があ り, 後者のほうが, ヒステリシス現象である wetting と dewettingの繰返しにより，損失が大きくなること が確認されている(4). 図 14(a)と (b)を比較すると, ( a )の場合には, スクイーズ効果が大きく,メニスカ

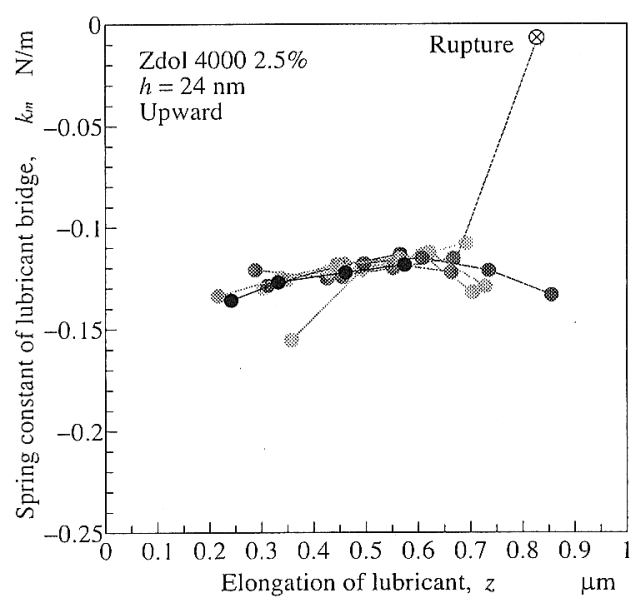

Fig. 8 Identified spring constant relative to bridge elongation for Zdol 4000 with film thickness of $24 \mathrm{~nm}$

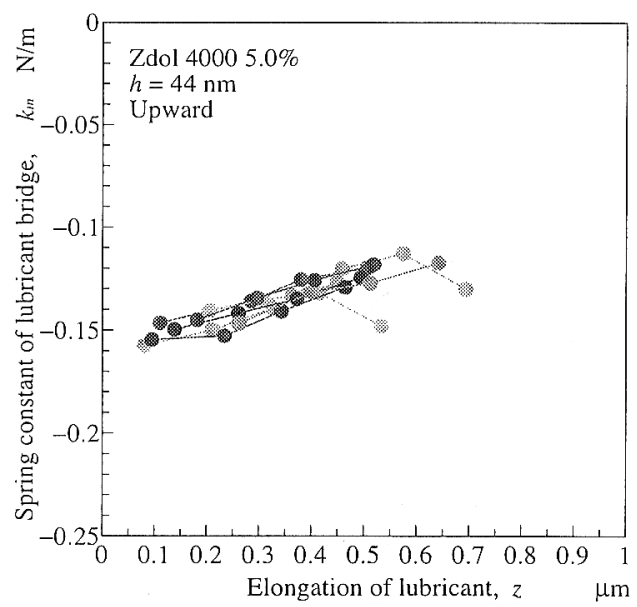

Fig. 9 Identified spring constant relative to bridge elongation for Zdol 4000 with film thickess of $44 \mathrm{~nm}$ 
ス内部の流体全体が移動して, 表面の変形が容易に生

じるために，接触扇変動が支配的であり，（b）の場合 には，スクイーズ効果が小さく，液架橋の中央部の分 子が移動しにくいために，触針に接触する分子と表面 との境界位置が変動する境界位置変動が支配的になつ ているものと考えられる。

以上の考察から，伸びが小さい領域では，損失の主 要因はスクイーズ効果であり，伸びとともに減少し， 伸びの大きい領域では，損失の主要因はメニスカスの 境界位㯰が変動するヒステリシスであり，伸びととも に増大すると考光ることができる。すなわち、これら の二つの效果が重量して，伸びに対してU字形の変

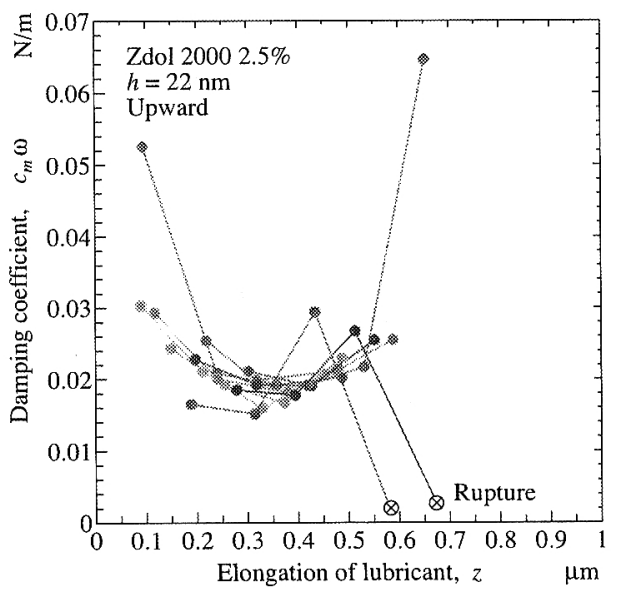

Fig. 10 Identified frequency-multiplied damping coefficient relative to bridge elongation for Zdol 2000 with film thickness of $22 \mathrm{~nm}$

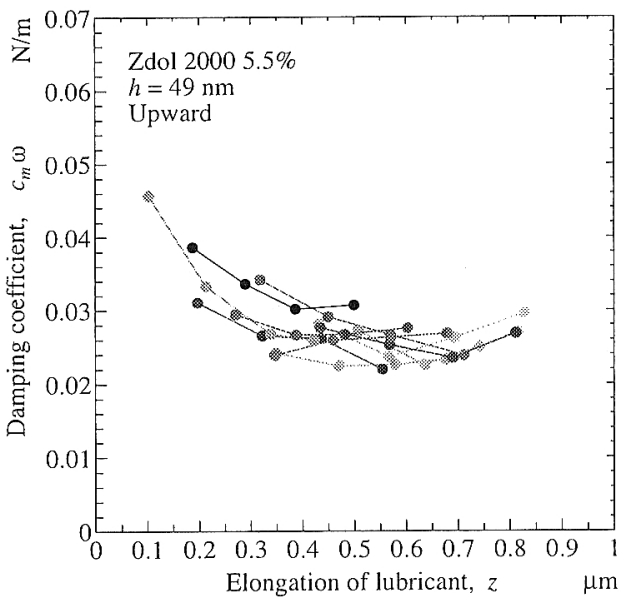

Fig. 11 Identified frequency-multiplied damping coefficient relative to bridge elongation for Zdol 2000 with film thickness of $49 \mathrm{~nm}$
化を示す特性が生じたものと推測できる。

なお，測定したばね定数はお扔むね $\mathrm{N} / \mathrm{m}$ ，減衰係数 $\times$ 角振動数はおお打和 $0.02 \sim 0.06 \mathrm{~N} /$ $\mathrm{m}$ であり, 曲率半径 $20 \mu \mathrm{m}$ の球を用いて測定された 従来の測定值 ${ }^{(5)}$ のおおむ称 10 分の 1 の微少量であ る.

\section{5. ま と め}

磁気ディスク表面に塗布されている PFPE 潤滑膜 の振動学的な特性を定量化するために, 先端曲率が $0.1 \mu \mathrm{m}$ のダイヤモンド製触針を用いて，極性基を持 つ潤滑風 PFPE Zdol 2000, Zdol 4000 (厚さ約 $20 \mathrm{nm,}$ 約 $40 \mathrm{~nm}$ )を整布したディスク面に接触させて,これ

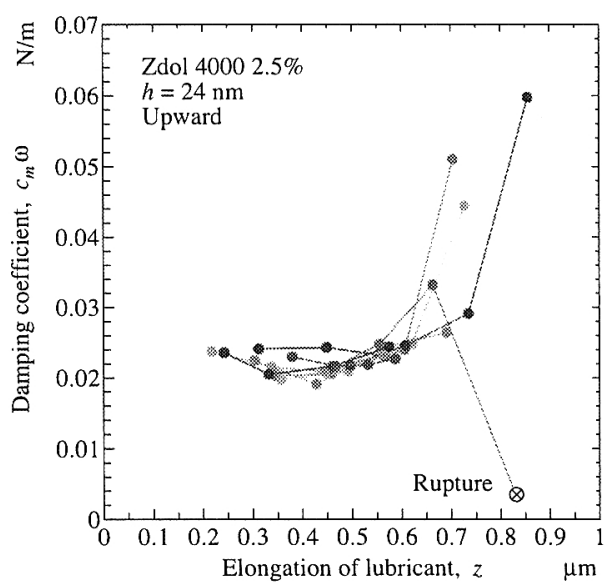

Fig. 12 Identified frequency-multiplied damping coefficient relative to bridge elongation for Zdol 4000 with film thickness of $24 \mathrm{~nm}$

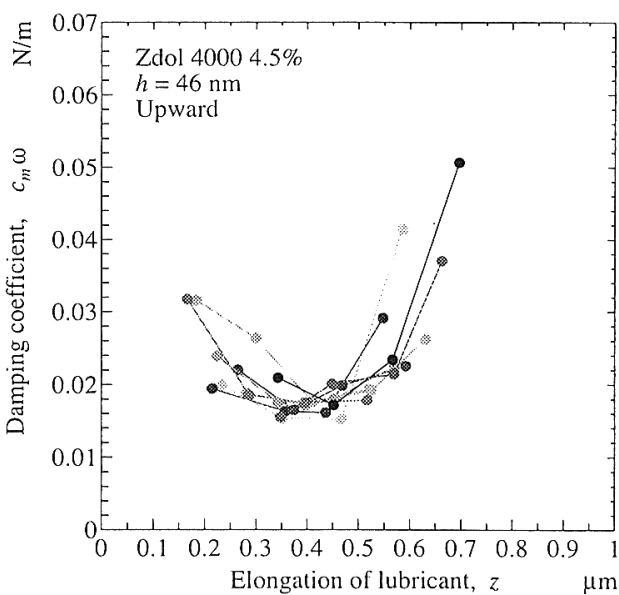

Fig. 13 Identified frequency-multiplied damping coefficient relative to bridge elongation for Zdol 4000 with film thickness of $46 \mathrm{~nm}$ 


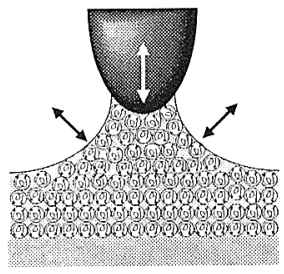

(a) Less elongation

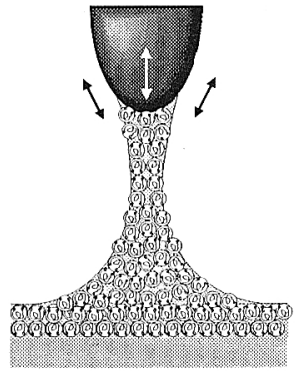

(b) Greater elongation
Fig. 14 Mechanism of damping action induced by meniscus motion

を階段状に上昇あるいは下降させて，階段状変位ごと に発生する過渡振動波形を回帰分析することにより， 振動パラメータを同定して, 50〜 $800 \mathrm{~nm}$ の範囲にお ける液架橋の長さに依存した液架橋のばね定数と減衰 係数を測定した，液架橋の伸びとともに，ばね定数の 絶対値, 減衰係数はともに減少し, 最小值をとった後 に増加に転じ，破断直前に急増することを見出した。

得られた結果を要約すると以下のとおりである。

（1）液架橋のばね定数 $k_{m}$ は負の值を持ち, 測定 された值は一-0.15〜-0.1 N/mであった．測定され た減衰係数 $c_{m}$ を減衰係数 $\times$ 角振動数, $c_{m} \times \omega$, とし て表示すると，その大きさは $0.02 \sim 0.06 \mathrm{~N} / \mathrm{m}$ であっ た。また, $\left|k_{m}\right|, c_{m} \times \omega と も に$, 液架橋の伸びととも に漸減し，最小值をとった後に増加に転じる。

（2）潤滑膜が薄い場合と厚い場合を比較すると, 膜が厚い場合のほうが, $\left|k_{m}\right|, c_{m} \times \omega$ の最小值を与え る伸び量がより長い側へ移行するとともに, これらの 值が増加に転じる特性が弱くなる.
（3）分子量が小さい場合と大きい場合を比較する と, $\left|k_{m}\right|$ については, 大きな差異はないが, $c_{m} \times \omega に$ ついては, 分子量が大きいほうが, 值が最小值をとっ たのちに増加に転じる特性が顕著に現れる。

（4）上記の特性を解析すると, 液架橋の減衰が生 起するメカニズムとして, 液架橋の伸びが短い領域で は，スクイーズ効果が支配的な要因であり，伸びが長 い領域では, メニスカスの境界位置が変動するヒステ リシス (wetting と dewetting)が支配的な要因と考え られる。

（5）先端の曲率半径が $0.1 \mu \mathrm{m}$ の触針で測定した $\left|k_{m}\right|, c_{m} \times \omega$ の值は, 曲率半径 $20 \mu \mathrm{m}$ の二つの球の間 に形成されたメニスカスに纱ける值のお拈々そ10 分 の 1 である。

本研究の一部は, 文部科学省産学官イノベーション 創出事業補助金 (13104) 抢よび平成 15 年度科学研究費 補助金 (15760305), 情報ストレージ研究推進機構, 愛 知江南短期大学特別研究糞の助成を得て実施された。 また，実験を支援した学生の服部真之君に謝意を表す る.

\section{文献}

(1) Israelachevili, J. N., J. Colloid Interface Sci., 110-1 (1986), 263-271.

(2) Choi, J. and Kato, T., Tribogy Int., 36 (2003), 475-481.

（3）伊藤伸太郎・福澤健二・張賀東 -三矢保永, 機論, 70-691, C (2004)，233-240.

(4) 松岡広成・福井茂寿・加藤孝久, トライボロジスト，4510 (2000), 757-768.

（5）崔埈豪・加藤孝久,トライボロジスト，48-10 (2003)，855865.

（6）三矢保永 - 大島康司, 機椧, 66-642, C (2000), 140-148.

（7）大島康司・三矢保永・岩瀬友輔, 機諭, 68-667, C (2002), 965-972. 